\title{
International Management: Enforcing Protection Of Foreign Intellectual Property In China
}

\author{
Elizabeth More, (Email: Elizabeth.more@vc.mq.edu.au), Macquarie University, Australia
}

\begin{abstract}
Over the last few years, China has escalated as a marketplace for Australian business and for higher education, with 55,000 Chinese mainland students officially recorded in 2003 (DEST, 2005). On the 18/4/05, China and Australia signed a formal statement of interest for commencing negotiations on a free-trade agreement, one which could eventually have wide repercussions for both business and education sectors (Taylor and Sutherland, 2005; DFAT, 2006). Already, a fastmoving China is transforming Australia (Dusevic, 2005). Consequently, we need to better understand the intellectual property (IP) issues confronting us in China, whilst exploiting its exciting opportunities, including its culture of education (Dusevic, 2005). This paper, therefore, considers a variety of issues impinging on evolution and enforcement of IP in China, taking note of key variables such as history, culture, politics and attitudes to law more broadly. It then examines current issues confronting IP protection. The paper concludes that understanding factors affecting enforcement are central to dealing with ongoing challenges to Australian business and education of China's piracy and counterfeiting.
\end{abstract}

\section{INTRODUCTION}

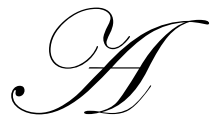

ustralia is considering entry into a free trade agreement with China, now the world's fastest growing major economy (DFAT, 2006). Alongside economic considerations, legal and regulatory issues dominate, including that of intellectual property. On a larger scale: 'Intellectual property has moved from a meager bilateral trade issue to the forefront of the international trade debate' ( $\mathrm{Yu}, 2000: 2)$. Certainly, Australian manufacturers are concerned about IP piracy as a central topic for any free-trade negotiations. This is not surprising, given that US firms lost at least \$US2.6 billion in 2004 to such piracy (Ryan, 2005, (c)). For Australian management education in China, recent figures show that 29 of our universities are involved in business and management education (AVCC 2003). Indeed, China is our largest market for student enrolments (DFAT, 2006).

There are numerous challenges in international business with China, including numerous transparency and restrictions issues (DFAT, 2006). These often go hand in hand with concerns over China's piracy problem, covering consumer goods and intellectual property - infringement of trademark, patent and copyright, at both domestic and international business levels - is a crucial issue (Evans,2003), particularly as 'Protection of intellectual property is an integral part of China's economic reform policy’(Lehman et al, 2002-3: 257).

China's commercial legal system is undergoing rapid change, in line with its global economic aspirations and resulting from its entry, as the $143^{\text {rd }}$ member, into the WTO in 2001. Its accession enables greater market access and, alongside legal developments, a much more predictable business environment is enticing new players into the Chinese marketplace. Another victory was won more recently when China was recognized by the Association of South-East Asian Nations trade ministers as a full market economy (Ryan, 2004 (b): 11).

Improving Intellectual Property Rights (IPR) legislation in compliance with WTO's Agreement on TradeRelated Aspects of Intellectual Property Rights (TRIPS) has been a crucial part of the new marketplace security. It 
demands that members reduce barriers to international trade by ensuring minimum standards of IP protection (Newberry, 2003).

Nevertheless, IP piracy and counterfeiting continue, putting in jeopardy the many gains made and making a mockery of attempts at statutory protection in a new and improved trading environment. As with much legislation and regulation worldwide, enforcement is a major challenge in this arena. It costs international trade an enormous amount, especially when piracy and counterfeiting are fuelled by recent technological developments, including the Internet.

\section{DIMENSIONS TO UNDERSTANDING PRC IP}

Utilizing purely Western perspectives to understand IP issues is inadequate and, given development of Chinese law occurs within socio-economic and political frameworks, we need to locate our discussion therein (Yongian, 2004). Restoring and developing China's legal system has been prioritized by the government, following the Maoist destruction of it. In 1997, the Chinese Communist Party nominated its highest priority as that of the rule of law (Orts, 2001).

Yet it remains to be seen whether China's recent push towards legislative change will overcome many major challenges, including that of ideological tensions between a rule of law and Chinese socialism, and whether we might be witnessing a real transition from rule by law to that of rule of law, the latter remaining for the present an ideal state for Chinese legal evolution. Moreover, rule of law is presently not possible because of obstacles that are cultural, structural and organizational. What is antithetical to such rule is the remaining influence of Confucianism, Legalism, and Communism; ongoing domination of society by the state; and the power of the CCP (Yongian, 2004).

Today, Yu (2002) claims China's 'self-strengthening worldview' reveals itself in rationalizations about helping to modernize China by reproducing foreign works, software and the like at no or little cost, sometimes perceived to be necessary owing to tight censorship.

\section{ISSUES}

China wishes to be regarded seriously in the international business arena and has recognized that to compete globally, and to encourage foreign trade, it must enforce fair rules of IP protection (Cook, 2002). Therefore, commercial legislation has escalated since China emerged from its political dark age and opened the country to world trade and the market economy. But legislative growth does not necessarily equate with practice, appropriate application, or enforcement. Moreover, in constitutional terms, translation of new legislation continues to be hampered because of the ongoing extra-legal actions of some government officials using Communist Party policies, as well as the lack of an independent judiciary. This is exacerbated because of legislative inconsistency, the complexity of diverse types of laws, insufficient resourcing, inadequate qualified lawyers, and corruption (Newberry, 2003). Further problems include:

... the difficulty in monitoring a large territory, the difficulty in collecting evidence of infringement and in collecting judgments, widespread corruption, abuse by government officials, different values placed on intellectual property infringement, the indistinguishability between public and private entities, local protectionism and the decentralization of government (Yu, 2000: 61-2).

Others emphasise enforcement difficulties due to:

China's reliance on administrative instead of criminal measures to combat IPR infringements, corruption and local protectionism at the provincial levels, limited resources and training available to enforcement officials, and lack of public education regarding the economic and social impact of counterfeiting and piracy (US DOC, 2004).

Broader explanations for the ongoing problems of Chinese piracy and counterfeiting reside in a business culture of 'guanxi' relationships and networks, Confucian beliefs, China's socialist economic system, the skepticism of Chinese leaders towards Western institutions, the populace's nationalist sentiments and xenophobia, governmental 
policies on censorship and information control, and major differences in China's judicial system and overall legal culture. These variables underlie the fact that major crackdowns and confiscation of pirated and counterfeit products do not always succeed in stemming the tide of IP law breaking, particularly in rural areas of the country. Nor is it clear whether we can be optimistic or pessimistic that legal reform and efforts at enforcement will continue now that China has WTO membership (Yu, 2000; Yu et al, 2003).

Regardless, the West needs to work out strategies for assisting China to meet its international IP obligations. Some solutions are increasing awareness programs, funding research into the issue (including into the tactic of public shaming), joint ventures, and encouraging more criminal and judicial actions (Yu, 2000). Others are more specific: increasing IP infringement, decreasing the burden on those prosecuting IP cases through decreasing the evidentiary standard and lowering the monetary threshold for bringing 'serious' charges against counterfeiters; enhancing customs surveillance; attracting more into the legal profession through incentives; and increasing IP enforcement education for Chinese legal professionals (Wang, 2000; Evans, 2003).

\section{CONCLUSION}

For many developing nations, the inherent tension between developing a legal system and being able to establish the rule of law, is a major challenge, not least for China during its transition to a major world economy. The potential is there for a transition from the recent adoption of positivist and instrumental rule by law, with an emphasis on consistency and uniformity of regulation, to building a normative rule of law. Yet its realization is far from clear in substance or in timing, although global citizenship through WTO membership should enhance the cultural and political changes required (Orts, 2001).

Therefore, it seems that we are still a way off from being able to guarantee the Australian Industry Group's demand that any FTA with China needs to go beyond a concern with tariffs to include protecting IP, appropriate regulatory structures, and the ability to enforce contracts with correct legal address (Ryan, 2004). Concern over protecting foreign IP remains strong:

China will remain an exceptionally challenging environment. It is a country with inadequate legal protections, rampant intellectual property rights violations, massive government interference .... There are many defenses against violations of intellectual property rights, such as compartmentalizing production know-how, opting for a WFOE rather than a joint venture, and highly automating the manufacture of complex products. But it is a basic reality that the Chinese have demonstrated a huge capacity for theft of intellectual property (Lieberthal \& Lieberthal, 2003: 70, 74).

Yet we need to recognise that IP crimes are world wide now, energized by ongoing technological developments and travel access. Furthermore, we should also remember the real cultural, social, political and economic differences between a Chinese and Western view and reality encompassing IP (Yu, 2000).

So, whilst China has escalated its IP legislative reform, implementing the letter of the law remains a key challenge in protecting both domestic and foreign IP rights in everyday commercial reality. In a climate of still relatively volatile and unstable political, economic and social development, this remarkable but still developing nation remains caught in the contradictions of a market economy constrained by a socialist straitjacket. Nevertheless, it must press on in meeting the demands of the global trading marketplace, challenged by its own internal opaque and complex systems, its Confucian and Communist heritage, its emerging legal system, and the behaviour of a still largely poor population, unconvinced of the virtues of Western IP expectations.

For Australia then, activities involved in international management covering China need to be informed by a better understanding of key issues in IP management. For those in business and management education, we need to grasp the issue of IP in an increasingly global, commercial and competitive education marketplace, one that remains a surprisingly dormant but potent concern. Nevertheless, as Healy (2006) advises, the new Australian Minister for Education, Julie Bishop, also warns that Australia's recent success in attracting large numbers of Chinese education candidates is likely to be challenged by the rise of Chinese education, especially at the postgraduate level, attracting 
the possible reverse flow of international students, including Australian ones. This may be no less true of trends in international business more generally. Such trends would necessarily pose different challenges in IP management in the global economy for education and business.

\section{REFERENCES}

1. Allison, J. and Lin, L. The Evolution of Chinese Attitudes Toward Property Rights in Invention and

2. Discovery (1999) 20 University of Pennsylvania Journal of International http://www.internationalecon.com/currentissues/china/bhattacharya.pdf

3. Commission for Intellectual Property Rights Report (2002) http://www.iprcommission.org/grapic/documents/final-report.htm

4. Cook, C. Patents, Profits \& Power. How Intellectual Property Rules the Global Economy (2002). England: Kogan.

5. Corne, P. Creation \& Application of Law in the PRC (2002) 50 American Journal Of Comparative Law 369.

6. DEST, 2005. A National Quality Strategy for Australian Transnational Education and Training: A Discussion Paper.

7. DFAT, 2006, Australia-china Free Trade Agreement Negotiations, http://www.dfat.gov.au/geo/china/fta.

8. Dusevic, T. The Quiet Revolution, Time, (25/4/05), 15.

9. Evans, A. Taming the counterfeit Dragon: The WTO, TRIPS and Chinese Amendments to Intellectual Property Laws (2003) 31 The Georgia Journal of International and Comparative Law 587.

10. Gewirtz, P. The U.S.-China Rule of Law Initiative (2003) William \& Mary Bill of Rights Journal 11, 603.

11. Healy, G. Bishop impresses on innovation (2006), Campus Review, 8/3/06, 6 .

12. Heasley, A. Lawsuits fly over copycat claims (2004) The Age 22 July, 5.

13. Human Rights in China, Funding the Rule of Law and Civil Society (2003) China Rights Forum 3, 22.

14. Jianming, C. WTO And The Rule Of Law In China (2002) 16 Temple International and Comparative Law Journal 370.

15. Lehman, E. Ojansivu, C, and Abrams, S, Well-Known Trademark Protection In The People's Republic Of China - Evolution Of The System (2002-2003) 26 Fordham International Law Journal 257.

16. Lieberthal, K. and Lieberthal, G. The Great Transition, (2003) Harvard Business Review 81 (10), 70.

17. Leiboff, M. and Thomas, M. Legal Theories in principle (2004). Australia: Lawbook Co.

18. Low, A. To Counterfeit In China Is Divine: Or Is It? (2002) Deakin Law Review 7 (1), 21-59.

19. Malanczuk, P. Akehurst's Modern Introduction To International Law. $7^{\text {th }}$ rev. ed. (1997). London: Routledge.

20. Newberry, W. Copyright Reform in China: A "Trips" Much Shorter and Less Strange than Imagined? (2003) 35 Connecticut Law Review 1425.

21. Orts, E. The Rule of Law in China (2001) 34 Vanderbilt Journal of Transnational Law 43.

22. Ruskola, T. Law Without Law, Or Is "Chinese Law" An Oxymoron? (2003) 11 William \& Mary Bill Of Rights Journal 655.

23. Ryan, C. (a), Business demands safeguards in China trade deal, Australian Financial Review, 3/9/04, 1 and 6.

24. Ryan, C. (b), Asean recognition big plus for China, Australian Financial Review, 6/9/04, 11.

25. Ryan, C. (c), Intellectual piracy on FTA table, Australian Financial Review, 21/3/05, 9.

26.

27. Taylor, L. and Sutherland, T. PM seals go-ahead for China trade talks, Australian Fin. Review, 19/4/05, 1. Wang, K. Chinese Commercial Law (2000). Melbourne: OUP.

28. Weinstein, V. and Fernandez, D. WTO Pushes China toward Greater IP Protection from Recent Changes in Intellectual Property Laws (2004) http://www.larta.org/lavox/articlelinks/2004/040712 wto.asp.

29. Williamson, P. Strategies for Competing in a Changed China (2004) MIT Sloan Mgt. Review 45 (4) 85.

30. World Intellectual Property Organization, http:/www.wipo.int/about-ip/en/ipworldwide/pdf/cn.pdf.

31. Yongnian, Z. Will China Become Democratic? (2004). England: Marshall Cavendish.

32. Yu, P. From Pirates to Partners: Protecting Intellectual Property in China in the Twenty-first Century. American University Law Review, (2000) 50 (1), 1.

33. Yu, P. The Second Coming Of Intellectual Property Rights In China (2002) 11 Occasional Papers in Intellectual Property from Benjamin N. Cardozo School of Law Yeshiva University 1.

34. Yu, P. et al, China and the WTO: Progress, Perils and Prospects (2003) 17 Columbia Journal of Asian Law 2. 